\title{
EXPERIMENTAL ASSESSMENT OF JUTE YARN AND STONE QUARRY DUSTON CONCRETE
}

\section{ROHIT KOTLA ${ }^{1} \&$ VIJAY KUMAR ${ }^{2}$}

${ }^{1}$ Post Graduate Student, Department of Civil Engineering, Chandigarh University, Gharuan, Mohali, Punjab, 140413, India

${ }^{2}$ Assistant Professor, Department of Civil Engineering, Chandigarh University, Gharuan, Mohali, Punjab, 140413, India

\begin{abstract}
In the present world, many types of research are going in the field of construction. As concrete is one of the important construction materials, many researches are going on in concrete. There are many different types of researches going around the world. The nature of the concrete is that the concrete is good in compression and weak in tension. In this research, a study is done on increasing the tensile strength of concrete to counteract the tension coming on a concrete member. To achieve an increased tensile strength of concrete jute yarn is added in the concrete mix with length 20mm, as jute yarn possess good tensile properties. As the production of jute yarn is very abundant in countries like India and Bangladesh. And to increase the compressive strength of concrete, stone quarry dust is added in concrete as a replacement of fine aggregate in the percentages as $10 \%, 20 \%$, 30\%, and $40 \%$. The optimum percentage of stone quarry dust is taken, where it shows the maximum strength, and also the optimum percentage of jute yarn is taken. Taking the optimum dosages of both the elements concrete cubes, beams, and cylinders are casted. Later all the tests of the concrete species are done such as compression test, split tensile test, and flexural test. The casting of cubes, beams, and cylinders was done by different percentages of stone quarry dust. After castings with different percentages of stone quarry dust the optimum percentage of stone quarry dust is obtained. The optimum dosage of jute yarn was also obtained similarly. After obtaining the optimum percentage of both the materials the cubes, beams, and cylinders were casted by adding both the materials in the concrete mix. Then the final results were obtained. The addition of stone quarry dust and jute yarn showed a good impact on the strength characteristics of concrete.
\end{abstract}

KEYWORDS: Jute Yarn, Stone Quarry Dust, Compressive Strength, Split Tensile Strength, Flexural Strength

Received: Jun 10, 2020; Accepted: Jun 30, 2020; Published: Jul 16, 2020; Paper Id.: IJMPERDJUN2020354

\section{INTRODUCTION}

\section{Stone Quarry Dust}

Stone quarry dust is a dust which is achieved by crushing the stones and rocks into small pieces. While crushing the stones and rocks the dust is produced which is called stone quarry dust. This crushing process of stones and rocks is generally done in the crushing plants or stone mines. Different types of materials are present in the stone mines such as clay, marble, granite, etc. When the stones in the mines are crushed to required sizes and shapes, then the dust is formed. This dust formed is generally a waste that we can use in the construction process. The Stone quarry dust is a fine material similar to that of fine aggregate. When compared with the strength of fine aggregate the stone quarry dust possesses little higher strength than the fine aggregate. So stone quarry dust can be used as an alternate material to the fine aggregate in the concrete mix. By this, the construction cost of the project can be reduced to a great extent, as the demand for fine aggregate is increasing day-by-day. The quarrying in the mines is done by 
different methods such as digging, by drilling holes, blasting, heating, etc. A large number of mines are present in the earth's crust. The quarrying of the stones is generally done from these mines. The stones are the elements that we generally get from the earth's crust. Some researchers say that stone quarry dust is also used in the production of concrete. The quarry dust particles can easily pass through $4.75 \mathrm{~mm}$ sieve. Many types of research are going out around the world to find an alternate material in the concrete mix in the place of natural sand. As the scarcity of sand in the use of construction is increasing day-by-day, we have to find an alternate material in the place of natural sand. Among many alternative materials found, stone quarry dust is one of them. Quarry dust gives more strength than natural sand up to the extent of a certain percentage when mixed in concrete. The quarry dust can be used for the construction of buildings, bridges, dams, etc. we can use this quarry dust in different civil engineering projects. Stone quarry dust can also be used in the construction of roads and pavements. The use of stone quarry dust in the construction process also decreases environmental pollution, as it is a major challenge to dump the quarry dust at different places as it causes environmental pollution.

\section{Jute Yarn}

Jute yarn is the material which is obtained from the jute plant. Jute yarn and jute twine these two materials are manufactured from jute fiber. About $90 \%$ percent of jute fiber is converted to jute yarns. These jute yarns have a variety of industrial applications. Slowly Jute is finding its way into the construction Industry. The natural fibers have a good advantage over synthetic fibers. The advantage of using natural fibers in the concrete mix is Impact loading. These natural fibers can counteract Impact loading. These natural fibers are more suitable for earthquake resistant structures. The disadvantage of artificial fiber is that they are non-existent in nature. Hence the natural fibers are used more in the concrete mix due to their various properties. The natural fibers are also environmentally friendly that is they do not cause any harm to the Environment. There are also many different uses of Jute yarns, the gunny bags are made by using these jute yarns. The jute fiber is required for making the jute yarns. These jute yarns are used for knitting the fabrics, they are also used for making decorative items. These jute yarns are similar to rope-like structures. The colors are added to these yarns by the bleaching method.

These jute yarns are generally produced from jute fibers which are produced mostly in South Asian countries like India and Bangladesh. The largest producer of jute in the world is India. These jute yarns have good tensile properties, they are also used for weaving. The jute fiber is used for making clothes. The jute crop requires very less amount of pesticides for production. These jute yarns increase the strength of concrete. They have numerous advantages over artificial fibers. The jute yarn is generally a natural material which is obtained from the plant. There is a process involved in taking out the jute yarn from the jute plant, as first the jute fiber is produced from the jute plant and later the jute fiber is converted into jute yarn. Many exports of the jute are done mostly from countries such as India and Bangladesh. Efforts have been done around the world in replacing cotton by Jute in many fields.

Concrete is a versatile material in the field of construction. Concrete is used for the construction of buildings, bridges, dams, etc. Many masonry structures are constructed with the help of concrete. Generally, concrete is a mixture of fine aggregate, coarse aggregate, and water. The different tests on concrete as a replacement of fine aggregate with stone quarry dust revealed that there is an upsurge of compressive resilience by $6.7 \%$ [1], 10.56\% [2], 22\% [3], 22.76\% [4], on the other hand, the tensile resiliency hiked by $7.78 \%$ [2], 13.47\% [4]. The optimal percentages of stone quarry dust as per literature is at 30\% [2], 40\% [3,5], and 50\% [4].The study of Jute yarn in concrete showed much higher tensile and compressive strength[6] when compared to conventional concrete. Another study pointed out that the addition of jute yarn 
by $0.1 \%$ improved the tensile strength[7] of concrete much significantly. By the addition of jute yarn, the compressive strength was about $36 \mathrm{MPa}$ and the split tensile strength was $3.2 \mathrm{MPa}$. Another investigation related to jute yarn on concrete [8]results in the increase in compressive, flexural, and tensile strength of concrete by $33 \%, 23 \%$, and $38 \%$ respectively as compared to conventional concrete. Although the size of fiber affects the strength of concrete and it was found in the literature [9] that larger the fiber length, the mechanical properties were found to affect adversely.

\section{MATERIALS AND METHODOLOGY}

\section{Cement}

Cement is a binding material which plays a very important role in the concrete mix. Cement binds the fine aggregate and coarse aggregate in the concrete mix. Different types of cement are available such as OPC and PPC. In this experiment, OPC 43-grade cement is used. The properties of the cement used is mentioned in the table

Table 1: Properties of Cement

\begin{tabular}{|c|l|c|}
\hline S.NO. & \multicolumn{1}{|c|}{ Description } & Results \\
\hline 1 & Specific Gravity of Cement & 3.3 \\
\hline 2 & Normal Consistency of Cement & $30 \%$ \\
\hline 3 & Fineness of Cement & 2.18 \\
\hline 4 & Initial Setting Time of Cement & 28 minutes \\
\hline 5 & Final Setting Time of Cement & 614 minutes \\
\hline 6 & Compressive Strength & 41.46 \\
\hline
\end{tabular}

\section{Fine Aggregate}

Fine aggregates are the materials that pass through $4.75 \mathrm{~mm}$ standard sieve. These fine aggregates are used in the concrete mix. The river sand is called a fine aggregate which is used in the concrete and mortar. The specific gravity of fine aggregate was 2.64 and the fineness modulus was 3.4 of grade II. The water-cement ratio taken in the mix was 0.36 . The specific gravity of the coarse aggregate selected was 2.68. The fineness modulus of the coarse aggregate used in the mix was 8.04. The coarse aggregate used was retained on $4.75 \mathrm{~mm}$ sieve.

Table 2: Experimental Data Conforming to IS 10262:2019 [10] and IS 456:2000 [11]

\begin{tabular}{|l|c|c|c|c|c|c|c|}
\hline \multicolumn{1}{|c|}{ Description } & Cement & Sand & $\begin{array}{c}\text { Stone Quarry } \\
\text { Dust }\end{array}$ & $\begin{array}{c}\text { Coarse } \\
\text { Aggregates }\end{array}$ & Jute Yarn & $\begin{array}{c}\text { Percentage of } \\
\text { Jute Yarn }\end{array}$ & $\begin{array}{c}\text { Percentage } \\
\text { of Stone } \\
\text { Quarry Dust }\end{array}$ \\
\hline NOMINAL & 1 & 1.47 & 0 & 2.83 & 0 & 0 & 0 \\
\hline 10\% S.Q,D & 1 & 1.323 & 0.147 & 2.83 & 0 & 0 & 10 \\
\hline 20\% S.Q.D & 1 & 1.176 & 0.294 & 2.83 & 0 & 0 & 20 \\
\hline 30\% S.Q.D & 1 & 1.029 & 0.441 & 2.83 & 0 & 0 & 40 \\
\hline 40\% S.Q.D & 1 & 0.882 & 0.588 & 2.83 & 0 & 0.25 & 10 \\
\hline $\begin{array}{l}\text { 0.25\% JUTE } \\
\text { YARN }\end{array}$ & 1 & 1.323 & 0.147 & 2.83 & 0.01325 & 0.5 & 10 \\
\hline $\begin{array}{l}\text { 0.5\% JUTE } \\
\text { YARN }\end{array}$ & 1 & 1.323 & 0.147 & 2.83 & 0.0265 & & 10 \\
\hline $\begin{array}{l}\text { 0.75\% JUTE } \\
\text { YARN }\end{array}$ & 1 & 1.323 & 0.147 & 2.83 & 0.03975 & 0.75 & \\
\hline
\end{tabular}

\section{Testing of Samples}

The casting and testing of the samples were done for 7, 14, and 28 days and the results were obtained. The compressive, split tensile strength, and flexural strength of the concrete was found out. The cubes of size $150 \mathrm{~mm} \times 150 \mathrm{~mm} \times 150 \mathrm{~mm}$ 
were cast for 7, 14, and 28 days and the compressive strength of the concrete were found out. The cylinders of dimension $150 \mathrm{~mm} \times 300 \mathrm{~mm}$ were casted to find out the split tensile strength of concrete. The beams of size $100 \mathrm{~mm} \times 100 \mathrm{~mm} \times 500 \mathrm{~mm}$ were casted to find the flexural strength of the concrete member. The compression strength of the beam specimen was performed on the compression testing machine. At first, the conventional concrete mix was casted for cubes, beams, and cylinders for 7, 14, and 28 days. Later the concrete mix was casted by replacing different percentages of stone quarry dust in fine aggregate. The stone quarry dust was added by the different percentages of $10 \%, 20 \% 30 \%$ and $40 \%$ in the place of fine aggregate. After that, the concrete specimens were cast by adding the jute yarn in the concrete mix in the percentages of $0.25 \%, 0.50 \%$, and $0.75 \%$ by the volume of concrete. The concrete specimens casted by adding stone quarry dust and jute yarn showed a good impact on the strength of the concrete. The grade of the concrete casted was M40.

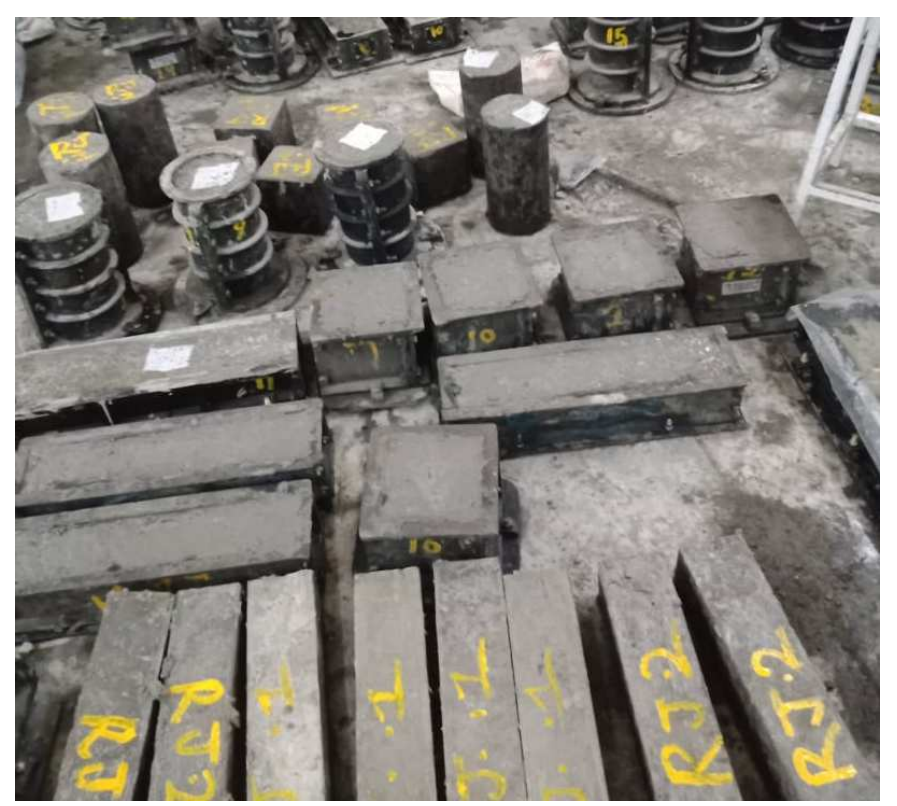

Figure 1: Casted Beams.

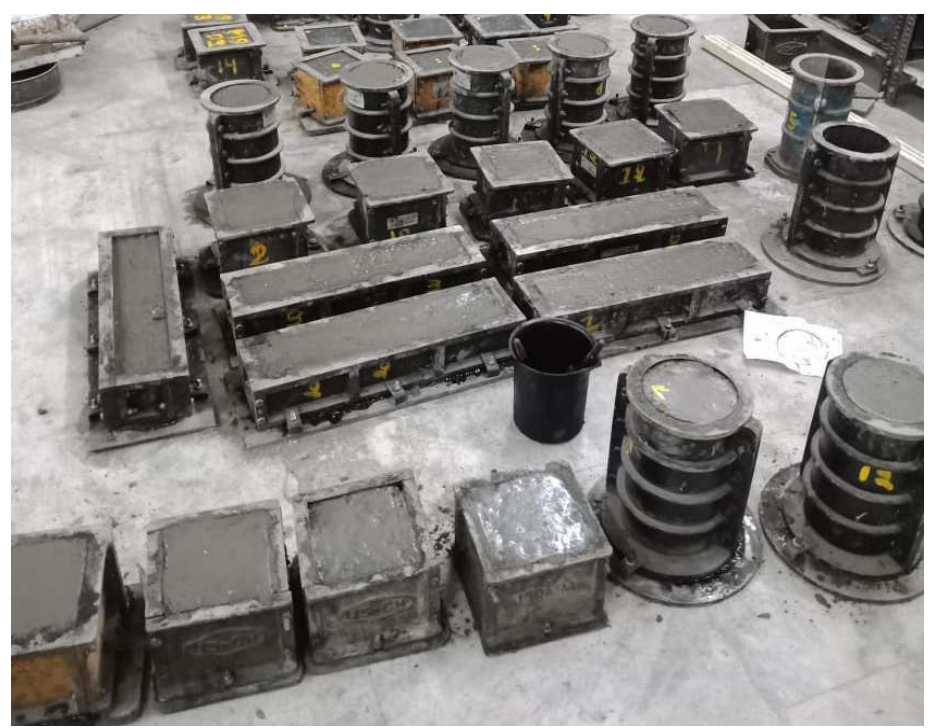

Figure 2: Casted Cubes and Beams. 


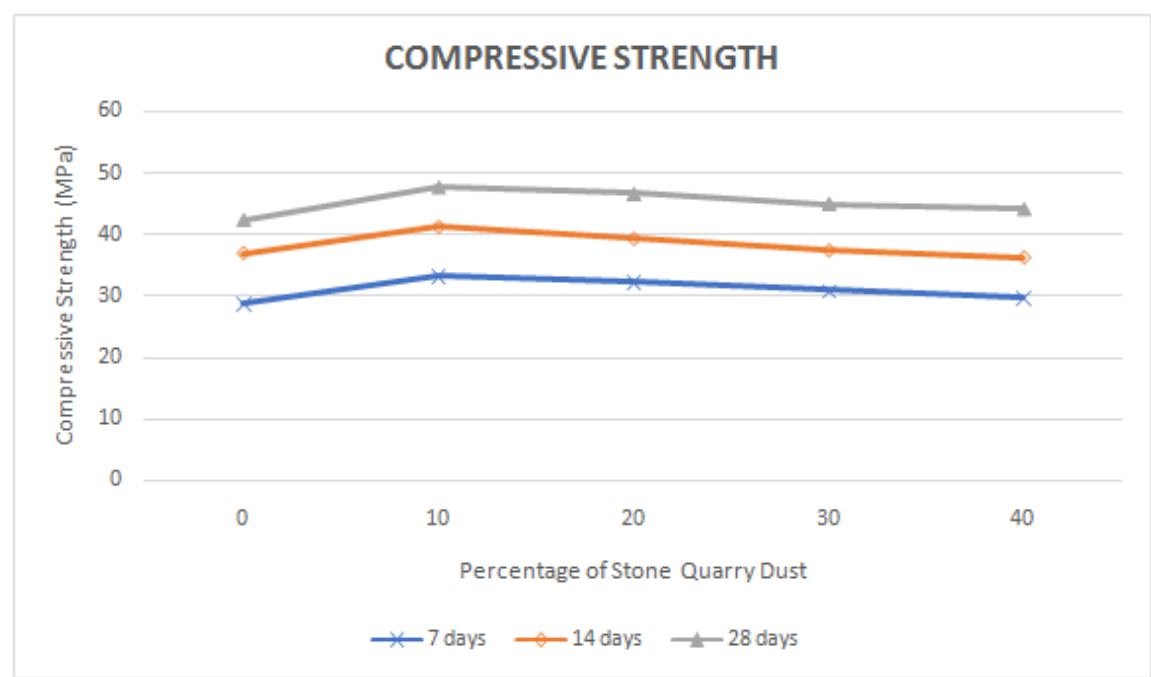

Figure 3: Compressive Strength by Adding Stone Quarry Dust.

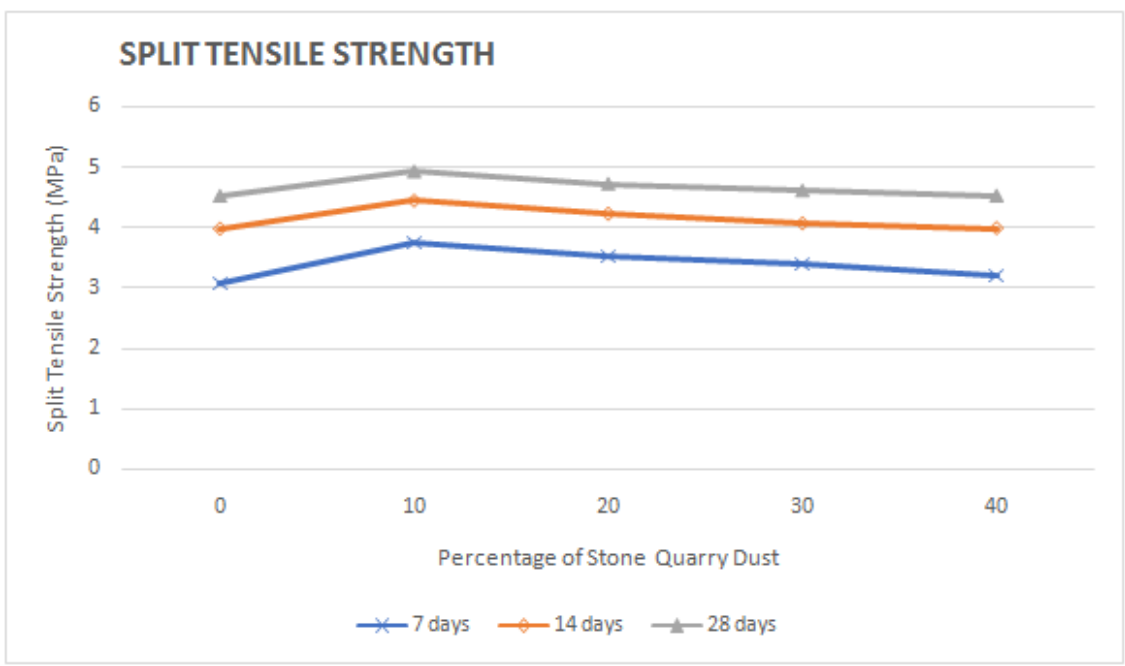

Figure 4: Split Tensile Strength by Adding Stone Quarry Dust.

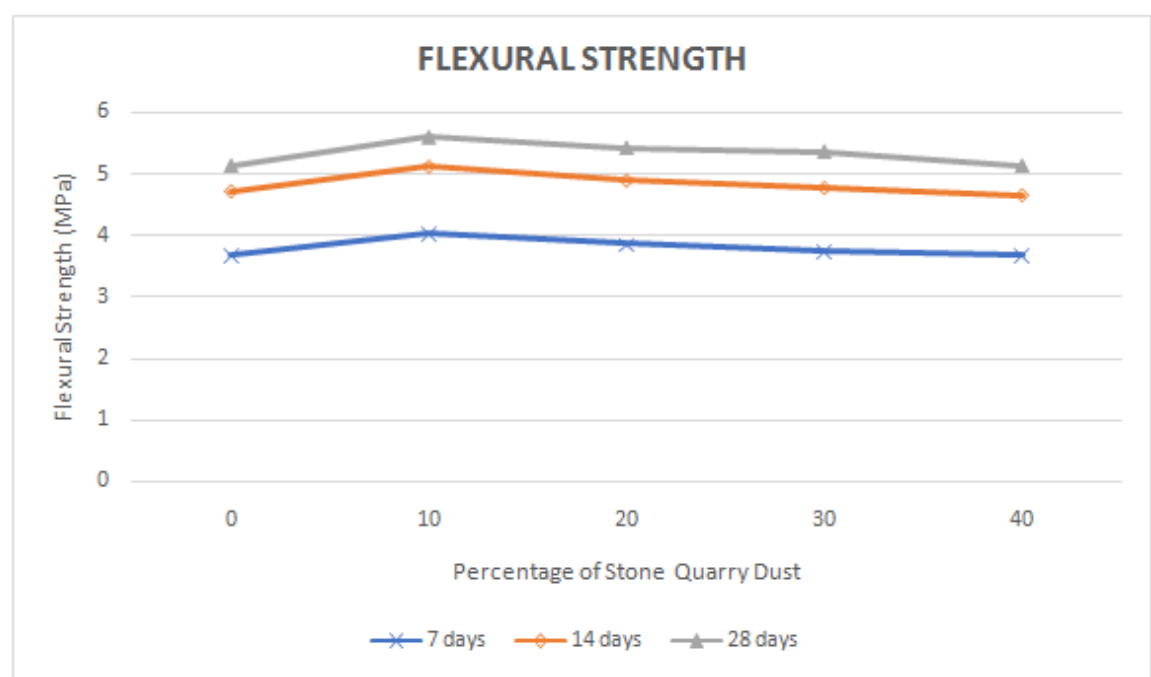

Figure 5: Flexural Strength by Adding Stone Quarry Dust. 


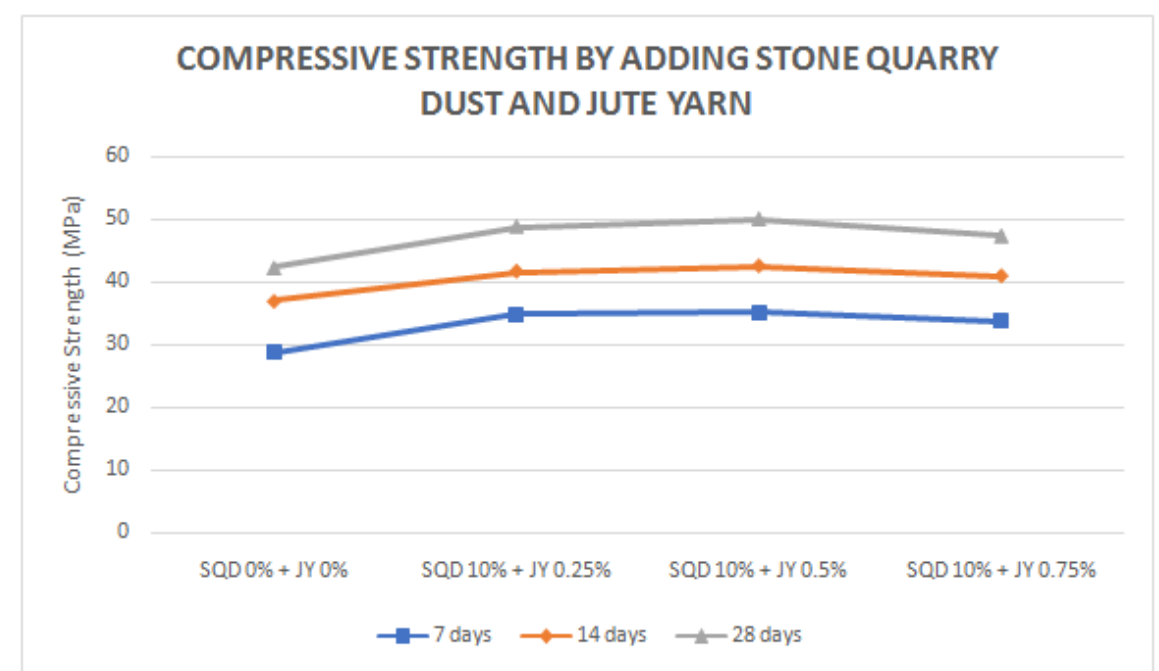

Figure 6: Compressive Strength by Adding Stone Quarry Dust and Jute Yarn.

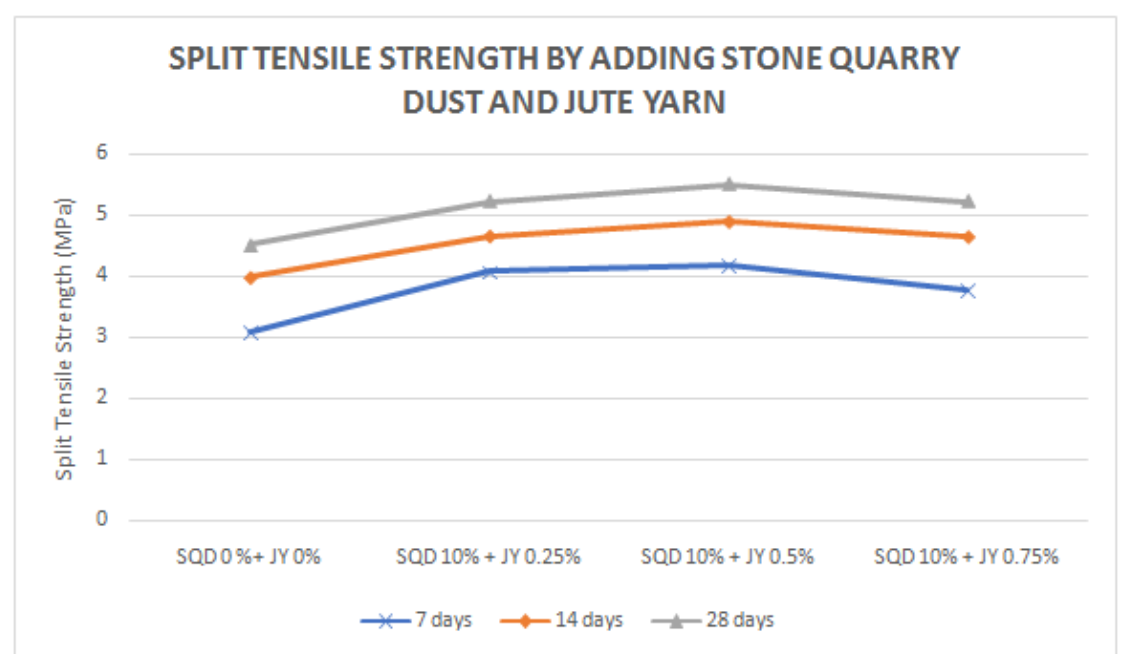

Figure 7: Split Tensile Strength by Adding Stone Quarry Dust and Jute Yarn.

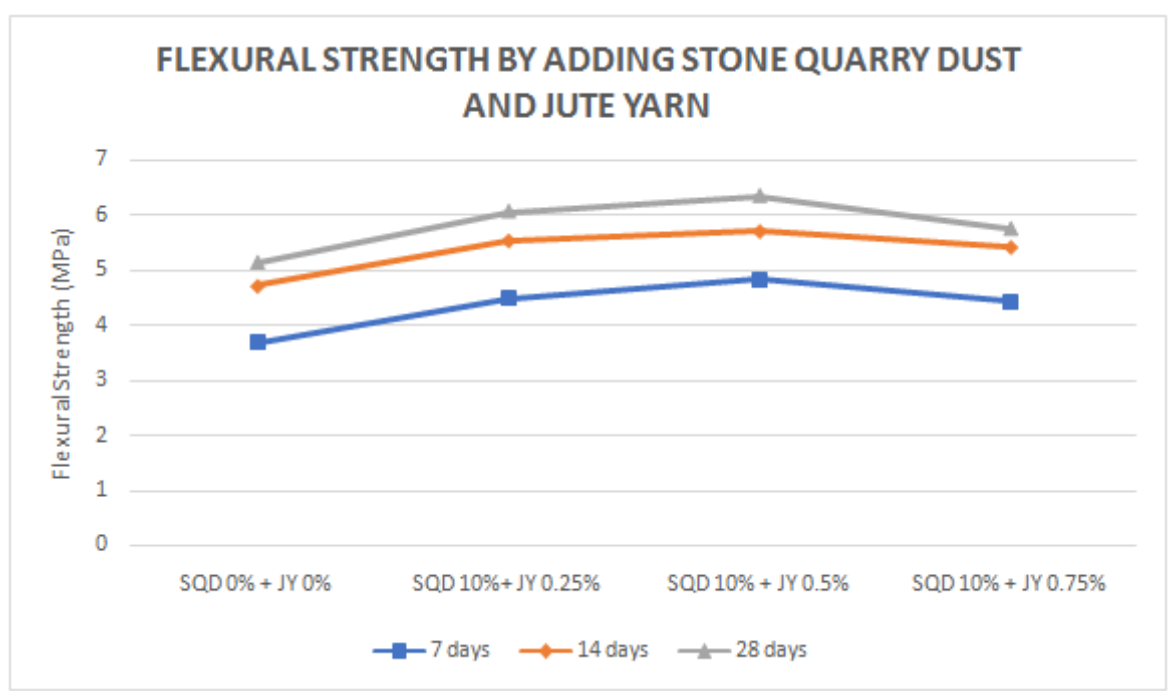

Figure 8: Flexural Strength by Adding Stone Quarry Dust and Jute Yarn. 


\section{CONCLUSIONS}

- The stone quarry dust was added in different percentages of $10 \%, 20 \%, 30 \%$, and $40 \%$. The optimum result was found in $10 \%$ replacement. The compressive strength was increased by $12.99 \%$ in 28 days testing when compared to conventional concrete by $10 \%$ replacement of fine aggregate with stone quarry dust.

- The optimum increase of split tensile strength was also found by $10 \%$ replacement of stone quarry dust. The split tensile strength was increased by $9.31 \%$ by $10 \%$ replacement of stone quarry dust.

- The maximum increase of flexural strength was also found by $10 \%$ replacement of sand by stone quarry dust.

- After all the results obtained by conventional concrete by stone quarry dust, we had added the jute yarn in different percentages by the volume of concrete. First, we had added the jute yarn in $0.25 \%, 0.50 \%$, and $0.75 \%$ and found the optimum percentage among them.

- The optimum percentage of jute yarn was found in $0.50 \%$ addition of jute yarn. Later the optimum percentages of both the materials i.e., stone quarry dust and jute yarn were taken and added in concrete.

- The compressive strength was found to be increased by $15.45 \%$ by $10 \%$ replacement of stone quarry dust and addition of jute yarn by $0.50 \%$.

- The split tensile strength of the concrete was increased by $15.74 \%$ by the addition of $0.50 \%$ of jute yarn. The flexural strength of the concrete was increased by $18.12 \%$ by replacement of stone quarry dust by $10 \%$ and the addition of jute yarn by $0.50 \%$.

\section{REFERENCES}

1. Hamid Mir A. Improved Concrete Properties Using Quarry Dust as Replacement for Natural Sand. Int J Eng Res Dev 2015;11:2278-67.

2. Priyatham B P R V S, Chaitanya D V S K, Dash B. Experimental study on partial replacement of cement with marble powder and fine aggregate with quarry dust. Int J Civ Eng Technol 2017;8:774-81.

3. Singh A K, Srivastava V, Agarwal V C. Stone Dust in Concrete: Effect on Compressive Strength Stone Dust in Concrete: Effect on Compressive Strength 2016.

4. Sinha S, Khan N, Soni P. An Experimental study on Effects of Quarry Dust as Partial Replacement of sand in concrete 2017:2021-3.

5. Shyam Prakash K, Rao C H. Study on Compressive Strength of Quarry Dust as Fine Aggregate in Concrete. Adv Civ Eng 2016; 2016. https://doi.org/10.1155/2016/1742769.

6. Katti M M, Nagendra M, Veda T, Bhavya T, Bharathesh S. EXPERIMENTAL STUDY ON JUTE YARN REINFORCED CONCRETE WITH GROUND GRANULATED BLAST FURNACE SLAG AND SILICA SAND 2018:172-6.

7. Olawale SOA. Supported by 2018; 3:347-51.

8. Zakaria M, Ahmed M, Hoque M M, Hannan A. Effect of jute yarn on the mechanical behavior of concrete composites. Springerplus 2015;4:1-8. https://doi.org/10.1186/s40064-015-1504-7. 
9. Zakaria M, Ahmed M, Hoque M, Shaid A. A Comparative Study of the Mechanical Properties of Jute Fiber and Yarn Reinforced Concrete Composites. J Nat Fibers 2018;00:1-12. https://doi.org/10.1080/15440478.2018.1525465.

10. Bureau of Indian Standards. IS 10262- 2019, Concrete mix proportioning- guidelines 2019:1-40.

11. IS 456:2000. Plain and Reinforced Concrete Arches. Bur Indian Stand Delhi 2000. https://doi.org/10.14359/8543.

12. Madhavi, K., and K. S. Jagadish. "Split Tensile Strength of Brick Masonry." International Journal of Civil Engineering (IJCE) 6.6 (2017): 1-8.

13. Shah, Aanal, and C B Shah. "Influence of Alkaline Activators and Temperature on Strength Properties of GGBS Based Geopolymer Concrete." International Journal of Civil Engineering (IJCE) 6.3 (2017):21-28

14. Wilson, Erin, and Nivin Philip. "The Influence of Fibres in Concrete: A Review." International Journal of Civil Engineering (IJCE) 4.6 (2015): 1-10.

15. Kiran, Tsai. "Comparision of Split Tensile Strength and Flexural of Glass Fiber Reinforced Concrete with Conventional Concrete." International Journal of Civil, Structural, Environmental and Infrastructure Engineering Research and Development (IJCSEIERD) 6.2 (2016):35-42

16. Rao, N. Venkat, B. Suresh, and K. Arun Kumar. "Evaluation of Mechanical Properties of Steel Fibre Reinforced Concrete with OPC43 and 53 Grades." International Journal of Mechanical and Production Engineering Research and Development (IJMPERD) 8.2 (2018): 221-228. 